\title{
Design and Synthesis of Redox-Switched Lariat Ethers and Their Application for Transport of Alkali and Alkaline-Earth Metal Cations Across Supported Liquid Membrane
}

\author{
Anubhuti Awasthy, Mamta Bhatnagar, Jyoti Tomar, and Uma Sharma \\ School of studies in Chemistry, Vikram University, Ujjain 456010, India
}

Received 14 April 2006; Accepted 27 May 2006

A new class of redox-switched anthraquinone derived lariat ethers 1-(1-anthraquinonyloxy) 3, 6, 9 trioxaundecane 11-ol ( $\left.\mathrm{M}_{1}\right)$, 1-(1-anthraquinonyloxy) 3, 6 dioxaoctane 9-ol $\left(\mathrm{M}_{2}\right), 1$-(1-anthraquinonyloxy) 3 oxapentane 5-ol $\left(\mathrm{M}_{3}\right), 1$-(1-anthraquinonyloxy) 3 oxapentane 5-butane $\left(\mathrm{M}_{4}\right)$, 1-(1-anthraquinonyloxy) 3, 6 dioxaoctane 9-methane $\left(\mathrm{M}_{5}\right)$ and 1-(1-anthraquinonyloxy) 3 oxapentane 5-methane $\left(\mathrm{M}_{6}\right)$ have been synthesized and characterized by spectral analysis. These ionophores were used in liquid membrane carrier facilitated transport of main group metal cations across supported liquid membrane (SLM). Cellulose nitrate membrane was used as membrane support. Effect of various parameters such as variation in concentration of metal as well as ionophore, effect of chain length and end group of ionophore have been studied. The sequence of metal ions transported by ionophore $\mathrm{M}_{1}$ is $\mathrm{Na}^{+}>\mathrm{Li}^{+}>\mathrm{K}^{+}>\mathrm{Ca}^{2+}>\mathrm{Mg}^{2+}$ and the order of metal ions transported by ionophores $\left(\mathrm{M}_{2}-\mathrm{M}_{6}\right)$ is $\mathrm{Li}^{+}>\mathrm{Na}^{+}>\mathrm{K}^{+}>\mathrm{Ca}^{2+}>\mathrm{Mg}^{2+}$. Ionophore $\mathrm{M}_{1}$ is selective for $\mathrm{Na}^{+}, \mathrm{Li}^{+}$, and $\mathrm{K}^{+}$and ionophores $\left(\mathrm{M}_{2}-\mathrm{M}_{6}\right)$ are selective for $\mathrm{Li}^{+}$and $\mathrm{Na}^{+}$.

Copyright (c) 2006 Anubhuti Awasthy et al. This is an open access article distributed under the Creative Commons Attribution License, which permits unrestricted use, distribution, and reproduction in any medium, provided the original work is properly cited.

\section{INTRODUCTION}

Carrier-assisted transport through supported liquid membranes is one of the important applications of supramolecular chemistry. The designs of redox-switched crown ethers and lariat ethers have been achieved by researchers [1] in 90s. Crowns are cyclic, introduced by Pedersen [2] in 1967; podands are acyclic, discovered by Vogtle and Angew Chem [3] in 1979; and a new class of crown ethers (combination of cyclic + acyclic) ionophores called lariat crown ethers [4], introduced by Gokel et al. Lariat ethers synthesized for the present study have redox moiety and different chain length of polyethers and have been used as a carrier in facilitated transport of alkali and alkaline-earth metal ions across supported liquid membrane (cellulose nitrate). We have already reported [5] isolation studies of main group $\left(\mathrm{Li}^{+}, \mathrm{Na}^{+}, \mathrm{K}^{+}\right.$, $\mathrm{Ca}^{2+}, \mathrm{Mg}^{2+}$ ) metal ions with redox-switched lariat ethers. The molecular architecture of lariat ether side arm holds the metal ions, and selectivity and carrier ability of redoxswitched lariat ethers will be helpful in constructing ionselective electrodes [6], redox-switchable devices [7], and specific carrier in separation of metal cations. Study of physiological reactions will also be carried out.

\section{EXPERIMENTAL}

\section{Synthesis of redox-switched lariat ethers}

We have synthesized ionophores $\left(\mathrm{M}_{1}-\mathrm{M}_{6}\right)$ as shown in Scheme 1.

Preparation of 1-[1-anthraquinonyloxy]-3, 6, 9-trioxaundecane-11-ol $\left(M_{1}\right)$ -

A solution of tetraethylene glycol $(2.89 \mathrm{~mL})$ in THF $(10 \mathrm{~mL})$ was added to vigorously stirred suspension of $\mathrm{NaH}$ ( $60 \%$ oil dispersion, $0.29 \mathrm{~g}$, and $7.25 \mathrm{mmol}$ ) in THF and the mixture was refluxed for 30 minutes. Then a solution of 1-chloroanthraquinone (1.28 g, $5.28 \mathrm{mmol}$ in THF) was added to it and refluxed at $80^{\circ} \mathrm{C}$ for 10 hours with stirring. This reaction was performed under nitrogen atmosphere. The reaction mixture was concentrated and the residue was mixed with $\mathrm{CH}_{2} \mathrm{Cl}_{2}$ and then washed with water (twice) followed by brine. The organic phase was separated and dried (over $\mathrm{MgSO} 4$ ), filtered, and concentrated. Column chromatography (silica gel, $2 \% \mathrm{MeOH} / \mathrm{CH}_{2} \mathrm{Cl}_{2}$ ) followed by recrystallization $\left(\mathrm{CH}_{2} \mathrm{Cl}_{2} /\right.$ hexane then $\left.\mathrm{EtOH}\right)$ gave $2.73 \mathrm{~g}(80 \%)$ of 


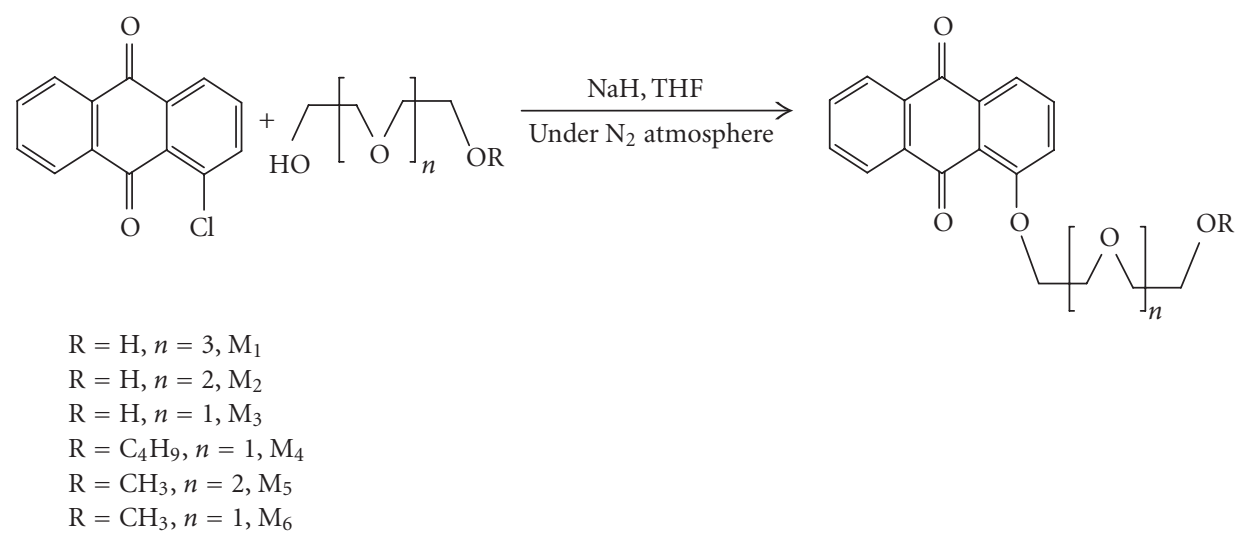

Scheme 1

ionophore $\mathrm{M}_{1}$ as a yellow solid.

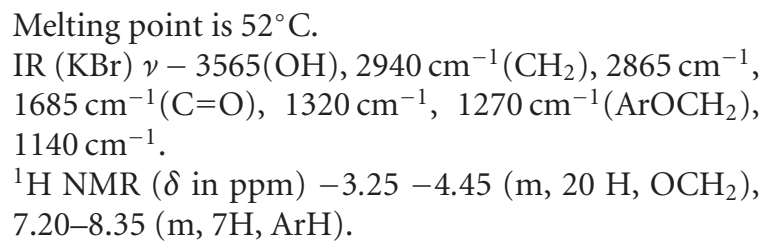

Ionophores $\mathrm{M}_{2}, \mathrm{M}_{3}, \mathrm{M}_{4}, \mathrm{M}_{5}$, and $\mathrm{M}_{6}$ were prepared in the same manner by taking triethylene glycol, diethylene glycol diethylene glycol monobutyl ether, and triethylene glycol monomethyl ether, diethylene glycol monomethyl ether [8], respectively (Scheme 1).

\section{Chemicals}

Metal salts as metal picrate (MPic) were prepared as reported earlier [9]. The reagents used in the synthesis of redoxswitched ionophores $\left(\mathrm{M}_{1}-\mathrm{M}_{6}\right)$ were 1-chloroanthraquinone (Lancaster), sodium hydride (Merck Limited, Mumbai, India), and tetraethylene glycol, triethylene glycol, diethylene glycol, diethylene glycol monobutyl ether, and triethylene glycol monomethyl ether, diethylene glycol monomethyl ether (Fluka Chemika-BioChemika, Switzerland). The solvents $\mathrm{CHCl}_{3}, \mathrm{CH}_{2} \mathrm{Cl}_{2}$, THF (Qualigen, Glaxo India Limited, Mumbai, India) were used as it is.

\section{Preparation of membrane}

Commercially available synthetic membrane Merck (cellulose nitrate) has been used as a support in SLM studies. The membrane pore size was $0.2 \mu \mathrm{m}$. Membranes were impregnated with redox-switched ionophores $\left(\mathrm{M}_{1}-\mathrm{M}_{6}\right)$, dipped overnight, and used as a membrane support. These impregnated membranes were used for carrier-facilitated transport studies of alkali and alkaline-metal cations. Electron microscope studies are under process (Figure 1).

\section{Carrier-mediated transport across supported liquid membrane}

Figure 1 shows the apparatus for this study. The supported liquid membrane [10] was positioned between two cylindrical half-cells. One cell compartment (source phase) contained an aqueous solution of the metal salt $(50 \mathrm{~mL})$ of $1 \times 10^{-1}$ and the other cell contained the receiving phase $(50 \mathrm{~mL})$ double distilled water separated by membrane having an effective diameter of $1 \mathrm{~cm}$. Both phases were stirred with magnetic stirrer at $120 \mathrm{rpm}$ at room temperature, the sample was withdrawn from the receiving phase after 24 hours and analyzed for sample using Systronics flame photometer $\left(\mathrm{Li}^{+}, \mathrm{Na}^{+}, \mathrm{K}^{+}, \mathrm{Ca}^{2+}\right)$ and $\mathrm{UV}-\mathrm{V}$ is a spectrophotometer for $\mathrm{Mg}^{2+}$. Cation flux $\left(J_{M}\right)$ values were calculated by using the relation [11]

$$
J_{M}=\frac{C(\text { receiving }) V}{(A t)},
$$

where $C$ is the concentration of cation in receiving phase in $\mathrm{mol} / \mathrm{dm}^{3}, V$ is the volume of receiving phase in $\mathrm{dm}^{3}, A$ is the effective area of membrane in $\mathrm{m}^{2}$, and $t$ is the time in seconds.

\section{RESULTS AND DISCUSSION}

Transport studies of metal ion across SLM were carried out by ionophores $\left(\mathrm{M}_{1}-\mathrm{M}_{6}\right)$ using cellulose nitrate membrane as a support. Blank experiments were also carried out for transport studies of metal salts in which membrane was devoid of carrier. No leakage of cation in the membrane was noted. The optimum concentration of metal ion and ionophore was found to be $1 \times 10^{-1} \mathrm{M}$ and $1 \times 10^{-4} \mathrm{M}$, respectively (Table 1 ).

The trend for the transport of cations with ionophore $\mathrm{M}_{1}$ is $\mathrm{Na}^{+} \gg \mathrm{Li}^{+}>\mathrm{K}^{+}>\mathrm{Ca}^{2+}>\mathrm{Mg}^{2+}$. Ionophore $\mathrm{M}_{1}$ having large tetraethylene glycol side chain with anthraquinone moiety shows maximum carrier ability. This is due to their flexible long chain length and additional donor sites for the interaction with all metal $\left(\mathrm{Li}^{+}, \mathrm{Na}^{+}, \mathrm{K}^{+}, \mathrm{Ca}^{2+}, \mathrm{Mg}^{2+}\right)$ cations. The trend for ionophore $\mathrm{M}_{2}$ is $\mathrm{Li}^{+}>\mathrm{Na}^{+}>\mathrm{K}^{+}$. Ionophore $\mathrm{M}_{2}$ having triethylene glycol chain shows strong binding affinity with high-charge-density cations, so it forms stable complexes with lithium. Therefore, it shows less transport for $\mathrm{K}^{+}, \mathrm{Na}^{+}$, and no transport for $\mathrm{Ca}^{2+}, \mathrm{Mg}^{2+}$. Ionophore $\mathrm{M}_{3}$ having small diethylene chain shows transport for $\mathrm{Li}^{+}>\mathrm{Na}^{+}$ only because small flexible side arm forms small pseudocyclic 


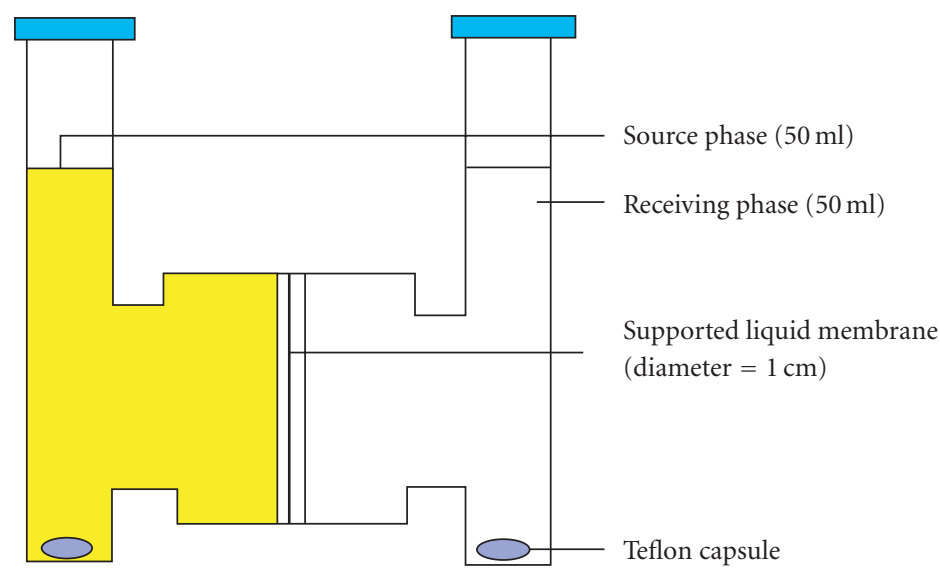

FIGURE 1: Apparatus for supported liquid membrane transport.

TABLE 1: Amount of metal cation transported in ppm with redox-switched lariat ethers $\left(\mathrm{M}_{1}-\mathrm{M}_{6}\right)$ through SLM by using cellulose nitrate

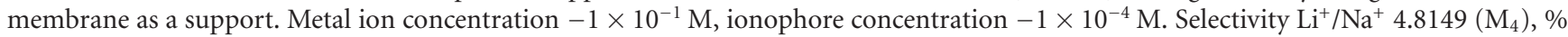
is the percentage of metal ion migration in 24 hours.

\begin{tabular}{|c|c|c|c|c|c|c|c|c|c|c|c|c|c|c|c|}
\hline \multirow{3}{*}{ Ionophore } & \multicolumn{15}{|c|}{ Amount of metal ions transported in ppm } \\
\hline & \multicolumn{3}{|c|}{$\mathrm{Li}^{+}$} & \multicolumn{3}{|c|}{$\mathrm{Na}^{+}$} & \multicolumn{3}{|c|}{$\mathrm{K}^{+}$} & \multicolumn{3}{|c|}{$\mathrm{Ca}^{2+}$} & \multicolumn{3}{|c|}{$\mathrm{Mg}^{2+}$} \\
\hline & $\begin{array}{l}\text { Cation } \\
\text { transp. }\end{array}$ & $\begin{array}{l}J_{M} \times 10^{-6} \\
\mathrm{~mol} / \mathrm{m}^{2} / \mathrm{s}\end{array}$ & $\%$ & $\begin{array}{l}\text { Cation } \\
\text { transp. }\end{array}$ & $\begin{array}{l}J_{M} \times 10^{-6} \\
\mathrm{~mol} / \mathrm{m}^{2} / \mathrm{s}\end{array}$ & $\%$ & $\begin{array}{l}\text { Cation } \\
\text { transp. }\end{array}$ & $\begin{array}{l}\mathrm{T}_{M} \times 10 \\
\mathrm{~mol} / \mathrm{m}^{2}\end{array}$ & & $\begin{array}{l}\text { Cation } \\
\text { transp. }\end{array}$ & $\begin{array}{l}J_{M} \times 10^{-} \\
\mathrm{mol} / \mathrm{m}^{2}\end{array}$ & & $\begin{array}{l}\text { Cation } \\
\text { transp. }\end{array}$ & $\begin{array}{l}J_{M} \times 10^{-6} \\
\mathrm{~mol} / \mathrm{m}^{2} / \mathrm{s}\end{array}$ & $\%$ \\
\hline $\mathrm{M}_{1}$ & 15.00 & 3.18 & 37.5 & 18.91 & 3.59 & 47.2 & 12.32 & 2.71 & 49.2 & 8.63 & 1.65 & 21.5 & 1.13 & 0.21 & 2.8 \\
\hline $\mathrm{M}_{2}$ & 8.93 & 1.92 & 22.3 & 3.22 & 0.81 & 8.0 & 3.11 & 0.78 & 12.4 & - & - & - & - & - & - \\
\hline $\mathrm{M}_{3}$ & 8.93 & 1.92 & 22.3 & 7.83 & 1.87 & 19.5 & - & - & - & - & - & - & - & - & - \\
\hline $\mathrm{M}_{4}$ & 13.53 & 2.81 & 33.8 & 3.12 & 0.78 & 7.8 & 1.13 & 0.21 & 4.5 & - & - & - & - & - & - \\
\hline $\mathrm{M}_{5}$ & 6.5 & 1.66 & 16.25 & 5.0 & 1.23 & 12.5 & 3.10 & 0.61 & 12.4 & - & - & - & - & - & - \\
\hline $\mathrm{M}_{6}$ & 25 & 5.21 & 62.5 & 13.5 & 2.61 & 33.75 & 2.0 & 0.41 & 8.0 & - & - & - & - & - & - \\
\hline
\end{tabular}

cavity by hydrogen bonding [12]. Ionophore $\mathrm{M}_{4}$ having butyl group and $\mathrm{M}_{5}, \mathrm{M}_{6}$ having methyl group shows order of transport for metal ion as $\mathrm{Li}^{+}>\mathrm{Na}^{+}>\mathrm{K}^{+}$.

Cation selectivity depends on the particular end group, when the end group is butyl, the ionophore $\mathrm{M}_{4}$ binds lithium in comparison to simple-OH group because conformational rigidity of the supporting framework does play a crucial role in binding. The conformation of side chain is such as to enclose the metal cation and there is interaction between coordinating site of the ionophore and the metal ion, as the end methyl group is not too strong. From the results, it is clear that $\mathrm{Mg}^{2+}$ cation is not transported in sufficient amount by this ionophore $\left(\mathrm{M}_{1}-\mathrm{M}_{6}\right)$ due to its highest charge density. Selectivity of ionophore $\mathrm{M}_{4}$ is shown at the bottom of Table 1 . Ionophore $\mathrm{M}_{6}$ having diethylene glycol monomethyl ether shows selectivity for $\mathrm{Li}^{+}$due to cavity fit concept. Ionophore $\left(\mathrm{M}_{1}-\mathrm{M}_{6}\right)$ shows selectivity towards $\mathrm{Li}^{+}$due to small size and higher charge density of $\mathrm{Li}^{+}$accounts for self-encapsulation [13].

The results inform us that the metal ion transport mainly depends upon the structure of the ionophores like number of donor sites, flexibility of chain length, ionophore concentration, and also on the concentration, charge density, and size of metal cation; and this molecular designing helps in fabri- cation of redox-switchable devices, molecular wires, as well as chemical sensors.

\section{ACKNOWLEDGMENTS}

We would like to thank Professor V. W. Bhagwat, Vikram University, Ujjain, S. M. Khopkar, IIT, Mumbai, and Professor Y. K. Agrawal, Nirma University, Ahmedabad, for their valuable guidance. Help of Dr K. P. Madhusudan, Central Drug Research Institute (CDRI), Lucknow, for spectral analysis is also acknowledged.

\section{REFERENCES}

[1] Chen Z, Gokel GW, Echegoyen L. Redox controlled chemical switching of cation transport in solid supported membrane system. Journal of Organic Chemistry. 1991;(56):3369-3372.

[2] Pedersen CJ. Cyclic polyethers and their complexes with metal salts. Journal of the American Chemical Society. 1967;89:70177036.

[3] Tummler B, Mass G, Vogtle F, Sieger H, Heimann U, Weber E. Open chain polyethers. Influence of aromatic donor end groups on thermodynamics and kinetics of alkali metal ion complex formation. Journal of American Chemical Society. 1979;101(10):2588-2597. 
[4] Gokel GW, Dishong DM, Diamond CJ. Lariat ethers. Synthesis and cation binding of macrocyclic polyethers possessing axially disposed secondary donor groups. Journal of the Chemical Society, Chemical Communications. 1980;(22):1053-1054.

[5] Bhatnagar M, Awasthy A, Sharma U. Stoichiometric complexes of some main group metal ions $\left(\mathrm{Li}^{+}, \mathrm{Na}^{+}, \mathrm{K}^{+}, \mathrm{Ca}^{++}\right)$ with redox-switched lariat ethers. Main Group Metal Chemistry. 2004;27(3):163-168.

[6] Shamsipur M, Avanes A, Javanbakht M, Ganjali MR, Sharghi H. A 9,10-anthraquinone derivative having two propenyl arms as a neutral ionophore for highly selective and sensitive membrane sensors for copper(II) ion. Analytical Sciences. 2002;18(8):875-879.

[7] Zon A, Palys M, Stojek Z, Sulowsska H. Supramolecular derivatives of 9, 10-anthraquinone. Electrochemistry at regular and low ionic strength and complexing properties. Electroanalysis. 2001;15:5,6.

[8] Awasthy A, Bhatnagar M, Joshi N, Sharma U. Effect of side arm chain length of redox ionophores on uptake of some metal ions. Indian Journal of Chemistry. 2006;45(5):1170-1172.

[9] Mishra D, Sharma U. Extraction and liquid membrane transport of some main group metal ions by hexaethylene glycol. Main Group Metal Chemistry. 1997;20(12):761-765.

[10] Khamaru S, Sharma U. A convenient method for the synthesis of bis[2-(2-carboxymethylphenoxy)ethyl] ether and bis[2-(2carboxyphenoxy)ethyl] ether and their application for transport of alkali metal cations across a supported liquid membrane. Journal of Chemical Research - Part S. 1998;(8):411.

[11] Mishra D, Sharma U. Extraction and bulk liquid membrane transport of some main group metal ions of facilitated by triethylene glycol monomethyl ether. Separation and Purification Technology. 2002;27(1):51-57.

[12] Ohki A, Iwaki K, Naka K, et al. Comparison of dibenzo-16crown-5 compounds with pendent amide groups as sodium ionophores in ion-selective electrodes and in solvent extraction. Electroanalysis. 2005;8(7):615-618.

[13] Echegoyen L, Gustowski DA, Gatto VJ, Gokel GW. Electrochemical switching of lariat ethers: enhanced cation binding by one- and two-electron reduction of an anthraquinone sidearm. Journal of the Chemical Society, Chemical Communications. 1986;(3):220-223. 


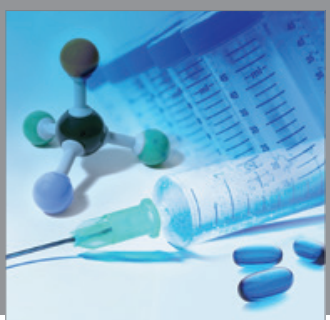

International Journal of

Medicinal Chemistry

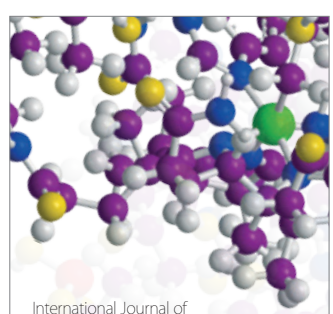

Carbohydrate Chemistry

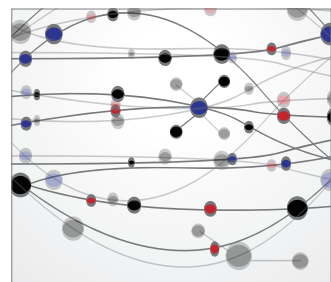

The Scientific World Journal
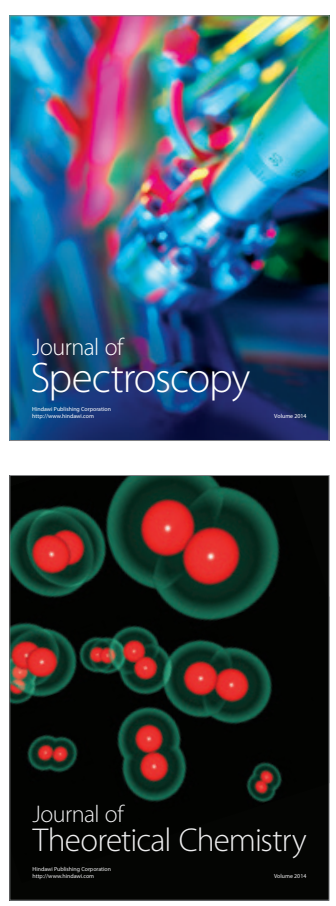
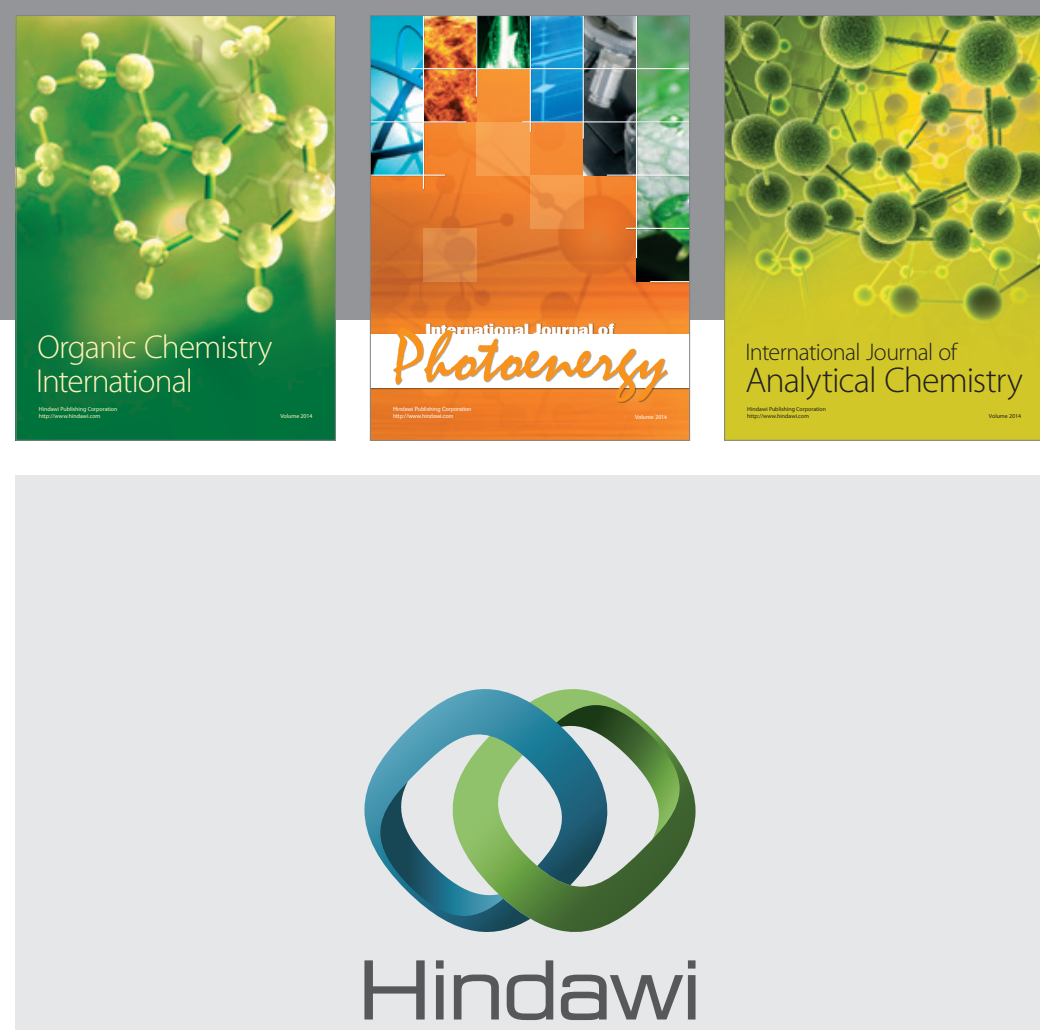

Submit your manuscripts at

http://www.hindawi.com
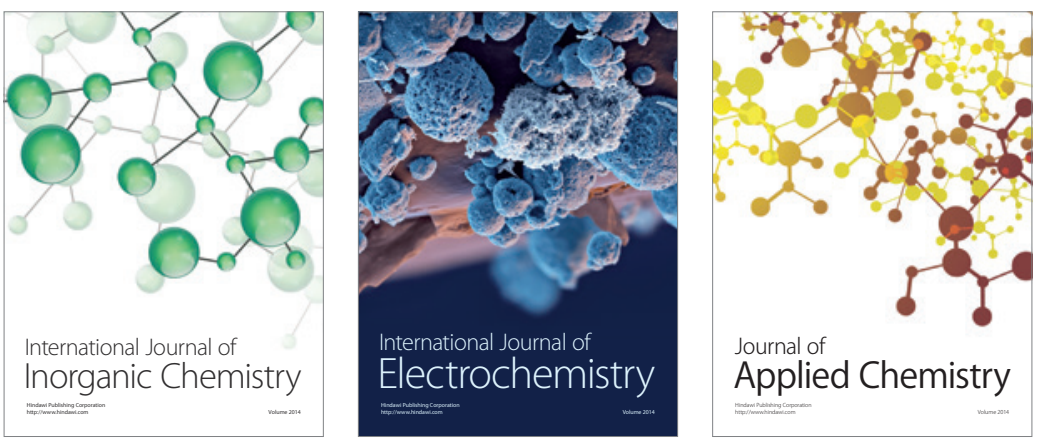

Journal of

Applied Chemistry
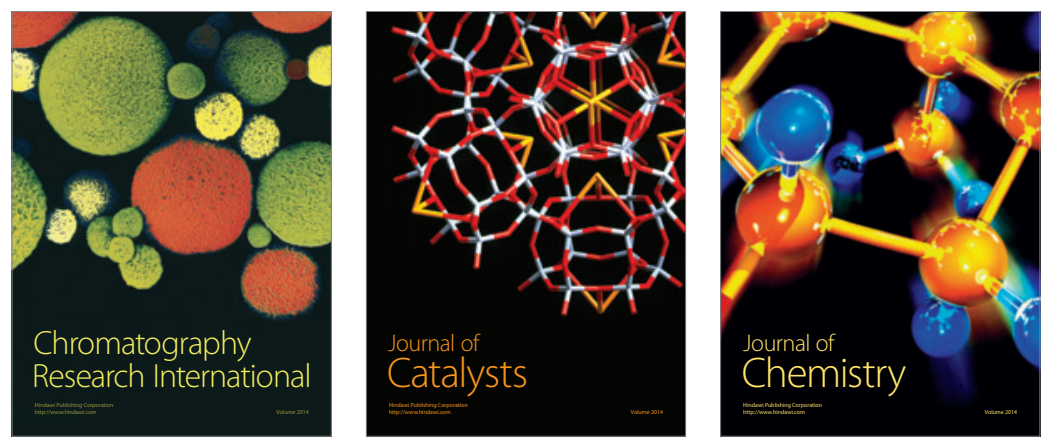
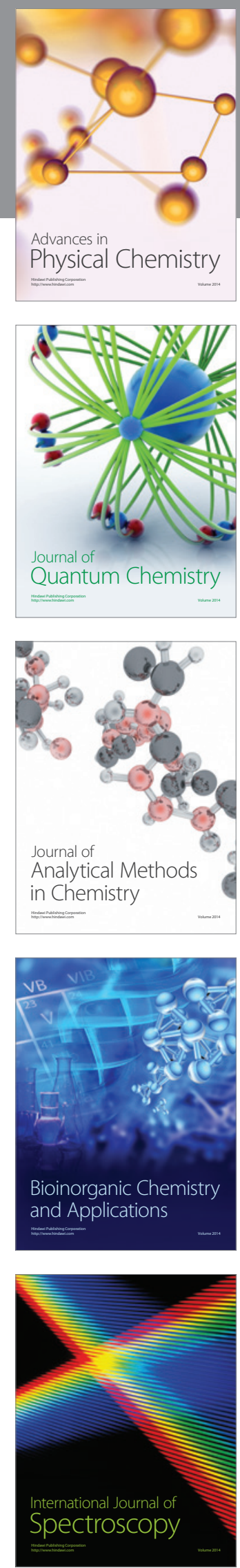